\title{
Professional Competences of Controllers: The Case of Poland
}

\author{
Bohumil Král-Grzegorz Mikołajewicz- \\ Jarosław Nowicki-Libuše Šoljaková*
}

\begin{abstract}
:
The article presents the results of the project regarding the development of the requirements to controllers' professional competences. The aim of the empirical part of the study is to assess the current situation in Poland in this field. During the study, opinions of two expert groups are compared. The respondents from the first group are responsible for development of controllers' professional competences and education. The respondents from the second group act as controllers in everyday business. The research refers to the following areas of controllers' work: their position in the company, general and specific content of controllers' activities, their authority and responsibility, requirements for education, requirements for ICT competencies, professional skills and practical experience, their role in ethical aspects of business, selection of potential candidates for a controller position, requirements to their continuing professional development and quality assurance of controllers' work as well as the importance of analysed areas for an effective controlling system in enterprise.
\end{abstract}

Key words: Controller; Professional competence; Education; Skills; Experience; Quality assurance.

JEL classification: M41.

\section{Introduction}

As Heraclitus of Ephesus stated, everything changes and nothing stands still. Permanent change also applies to business management. The change in company management manifests itself in various areas and applies to management instruments, methods as well as information support used (Král, Šoljaková, 2015).

These changes influence many features of business, including qualitative aspects of controllers' work. This is manifested in particular by:

\footnotetext{
Bohumil Král; University of Economics, Prague, Faculty of Finance and Accounting, Department of Management Accounting, W. Churchill Sq. 4, 13067 Prague, Czech Republic, <kral@vse.cz>. Grzegorz Mikołajewicz; Poznan University of Economics and Business, Department of Controlling, Financial Analysis and Valuation, Poznań, Poland, <g.mikolajewicz@ue.poznan.pl>. Jarosław Nowicki; Poznań University of Economics and Business, Department of Controlling, Financial Analysis and Valuation, Poznań, Poland, <j.nowicki@ue.poznan.pl>.

Libuše Šoljaková; University of Economics, Prague, Faculty of Finance and Accounting, Department of Management Accounting, W. Churchill Sq. 4, 13067 Prague, Czech Republic, <soljak@vse.cz>.

The article has been developed as one of the outcomes of the IGA project no. F1/57/2014 The international comparison of requirement on professional competence of company controllers.
} 
- new requirements on controllers' work - formulated by companies; and

- the reactions of universities, business schools and accounting-oriented professional bodies which implement new requirements into curricula and certification systems as a response to those changes.

Significance of abovementioned issues for both theory and practice of controlling makes the goal of the paper especially important. The general purpose of the project was to examine the requirements to professional competence development of controllers. This paper discusses the case of Poland.

The project was initiated in 2011 by the International Group of Controlling. However, after defining the first conceptual outcomes it was interrupted in international dimension with the recommendation to national professional bodies to implement it on the national basis first.

Polish version of the project has been running since the beginning of 2015 at the Department of Controlling, Financial Analysis and Valuation at Poznań University of Economics and Business. The framework of the research comes from the Czech version of the project (Kral, Šoljaková, 2016), that has been running since 2012 at the Department of Management Accounting at the University of Economics, Prague. The research team has been drawn on the International Group of Controlling $(2010,2011)$ conceptual outcomes. Further elaboration of the problem has led to a revised project framework with crucial empirical part. The aim of the empirical study has been to define and analyse the most important requirements to professional competences of controllers in Czech Republic and other European countries. The purpose of the following stage undertaken in 2015 is to compare the results of empirical research among different countries.

This paper describes and evaluates the results of the empirical research on the requirements of controllers' work in Poland. To examine the requirements to professional competence development of controllers, authors analysed the questionnaires of two groups of respondents: experts originating from business schools and universities as well as controllers and managers operating in companies. Questionnaires referred to such issues as position of controllers in the organization, structure of controlling departments, relation of these departments to other financial management departments, content of the controllers' activities, authority and responsibility of controllers, requirements for education, professional skills and practical experience, controllers' role in ethical aspects of business, continuing professional development, quality assurance of the controllers' work as well as importance of the aforementioned areas for an effective controlling system in enterprise.

The further part of the paper is organised as follows. The first section presents the literature review in order to show broader context of the conducted research. The 
second section describes research design and methodology. Following with the third section which presents the most important empirical results in abovementioned areas along with the discussion. Lastly, the conclusions summarise main findings of the paper.

\section{Literature review}

The topic which is the subject of the article is not elaborated in the papers dedicated to the controllers' professional competence development exclusively; some papers discuss the importance of this issue in broader context. Some of relevant literature sources are mentioned; they are ordered from the most general to more specific ones.

Proper management has great importance for a company in a changing business environment (Merchant, 2003; Kaplan and Cooper, 1998; Burns and Yazdifar, 2001; Kaplan and Anderson, 2007; Sierpińska and Niedbała, 2003; Marciniak, 2008). The most important factors influencing the company management include its inter-disciplinary substance, multidimensionality and strategic perspective, as well as the integration of inter-relationships between the users and data processing information systems (Simons, 2004; Parker, 2002; Merchant, 2003).

This situation has a significant impact not only on the substance of the company management control system, including its information support (Carruth, 2004), but also on the professional education, skills, knowledge, experience and ethical approaches, values and attitudes of financial managers.

Some authors devote special attention to controllers or managerial accountants whose professional competence is the principal subject of the paper. For example Kaplan (1998) states that the changes in business management accompanied by ICT development enable these professionals to break out of the routine data processing, which allows them to spend less time on standardized statements, give more attention to analysis of submitted information, communicate companies' goals and ways of achieving them to right people (responsible for goals' achievement) and concentrate on decision-making process concerning the future of the company (instead of continuous comparing results with plan).

As correct decision-making is becoming a foundation for competitive advantage and value creation (CIMA, 2008, 2009), controllers have an important role to play in the decision-making. The main challenge for the finance and accounting support of management is how to develop controllers who will be able to cooperate with managers and support their decision-making process.

When analysing the changing role of managers, controllers and interactions among them Zralý (2007) reaches the conclusion that both controllers and managers should follow the approach which he calls the "controlling convergent concept". 
According to Grandlund and Lukka (1998) controllers (management accountants) should not act only as information support providers, but more as business partners to managers. Many other researchers also see the controller as business partner to manager in a process of strategy implementation (Steinke et al., 2014, Sierpińska and Niedbała, 2003; Jaruga, Nowak and Szychta, 1999), although specific requirements, position in the organizational structure as well as understanding of controller's role in a company can differ among companies and countries (Marciniak, 2008; Kes, 2013; Janik and Paździor, 2012; Szychta, 2011; Janczyk-Strzała, 2008; Bieńkowska, Kral and Zabłocka-Kluczka, 2014; ForemnaPilarska, 2015).

All the above-mentioned changes in the content of controllers' work have caused changes in the requirements for their professional competences. Traditional requirements for controllers' professional competences included good knowledge, hard and soft skills and experience of the management accounting instruments and methods, and their implementation and use in the company information systems. Nowadays controllers are rather expected to be competent to use this knowledge, skills and experience for the purpose of integrating management accounting information with other non- financial information on an interdisciplinary basis. They should be able to justify, interpret and present the results for the whole company as well as its sections, to provide quality information support for decision-making process and to enhance synergies through the communication and integration of the relations they develop (Burns and Yazdifar, 2001; Yasin, Bayes, Czuchry, 2005; Hoper, 1980; Horváth, 2006; and Zralý, 2007; Sierpińska and Niedbała, 2003; and Marciniak, 2008).

Moreover, the ability to argue, interpret and present results and to link appropriate information with intangible sections of business activities along with other "soft" skills is increasingly more important (Pierce and O'Deam, 2003; Grandlund and Lukka, 1998; Jablonsky, Keating and Heian, 2004 and Yasin, Bayes, Czuchry, 2005). This leads researchers to investigate very specific features concerning interdisciplinary nature of controllers' characteristics, for example psychological and gender issues (Gmińska, 2014; Nowak, 2013; Nowak, 2014a; Nowak 2014b).

It is crucial to emphasize the necessity to perceive, support and communicate ethical and moral values, approaches and attitudes (Yasin, Bayes, Czuchry, 2005; Pierce and O'Deam, 2003; Grandlund and Lukka, 1998; Jablonsky, Keating and Heian, 2004), because these factors have been undervalued in all frequently quoted materials devoted to professional competence development of controllers as well as in practice. 


\section{Research methodology}

Research methodology used in the project includes different methods (KrálŠoljaková, 2014, Král - Šoljaková 2016).

The most general research method used in the paper is comparison - it was carried out in following areas:

- comparison of existing standards with literature sources; standards define requirements for the controllers' professional competence and the literature sources examine the influence of business environment changes on the professional competence of controllers; this type of comparison has been used especially in the conceptual part of the research and when developing the structure and content of the questionnaire;

- comparison of above-mentioned tendencies with recent practice in selected companies;

- comparison of how this practice is perceived and implemented:

- by those experts who are responsible for the controllers' professional competence development and education, and

- by those experts who actually operate in business.

Aforementioned types of comparison led to the selection of two groups of experts, who became the addressed respondents of the questionnaires.

Other methods used when solving the problem include descriptive and statistical methods, synthesis and analysis, analogy and generalization. There were used in the following ways:

- descriptive methods were used mainly to define the requirements for controllers' professional competence development;

- statistical methods were used to describe trends and relations in the empirical part of the project as well as to present statistical inference (the Shapiro-Wilk normality test was used to examine whether the data is from a normally distributed population and the Mann-Whitney $U$ test was used to ascertain whether the differences between opinions of both groups of experts are statistically significant);

- methods of synthesis and analysis were used during the questionnaire development (when considering the aims, content and structure of the questionnaire);

- analogy was used during the questionnaire development, especially in the parts dedicated to education, skills and practical experience requirements for controllers; and

- generalization was used when formulating the principal project outcomes.

All of the above-stated methods constitute a system approach. 
The purpose of the empirical part of the research was to map the general tendencies of the requirements on controllers' professional competences. In order to achieve this goal, two groups of respondents were addressed:

- experts originating from business schools and universities responsible for controllers' competence development in the initial stage;

- controllers and managers operating in companies - perceiving the requirements on the controllers' professional competence from the business reality perspective.

Addressing two groups of respondents required two versions of the questionnaire:

- a version titled "A controller should be...", designated for the first group of experts; and

- a version titled "A controller is.", designated for the second group.

The respondents from the first group are members of accounting, controlling and finance departments at various Polish business university centres, i.e.: Cracow University of Economics, Nicolaus Copernicus University in Torun, Poznań University of Economics and Business, SGH Warsaw School of Economics, University of Economics in Katowice, University of Gdansk, University of Lodz, University of Szczecin and Wrocław University of Economics.

The respondents in the second group have been controllers or managers of randomly selected Polish as well as foreign companies operating in various industries in Poland (i.e. insurance, banking, medical care, construction, FMCG, retail, passenger transport, logistics, alcohol, tobacco, marketing, machine producers, furniture manufacturing, water supply, metallurgical and chemical industry). $46 \%$ of companies in the sample have assets exceeding $€ 20 \mathrm{~m}, 38 \%$ between $€ 2-20 \mathrm{~m}$ and the rest less than $€ 2 \mathrm{~m}$. Over $58 \%$ of the companies have a turnover less than $€ 40 \mathrm{~m}$ and two groups of companies, sales between $€ 40-400 \mathrm{~m}$ and over $€ 400 \mathrm{~m}$, reached the same share of $21 \%$ each. According to the employment, nearly $42 \%$ of companies have a number of employees exceeding 500 , ca. $38 \%$ between $50-500$ and over $20 \%$ less than 50. Concerning ownership $-46 \%$ of them are part of concern, $21 \%$ owned by sate or municipality and $33 \%$ have individual owners. The respondents have been working in their position for less than 10 years $(58,5 \%), 10$ - 20 years $(29 \%), 21$ - 30 years $(4 \%)$ and more than 30 years $(8,5 \%)$. A little more than half of them $(58 \%)$ are men. Both versions of the questionnaire were very similar regarding their structure and content. They originated from the conceptual outcomes of the previous stage of the project. Most of the questions in both versions of the questionnaire required answers scaled from 1 (strong disagreement) to 5 (strong agreement). A limited part of the questions required Yes or No or open answers. 
Questions in both versions of the questionnaire referred to following areas:

- the position of controllers in the companies' organizational charts;

- the structure of departments of controllership;

- the relationship of these departments to other financial management departments;

- the general content of the controllers' activities;

- the areas and extent of the controllers' authority and responsibility;

- the specific content of the controllers' activities;

- requirements for education;

- requirements for professional skills and practical experience;

- controllers' role in ethical aspects of business;

- selection of potential candidates for a controller / management accountant positions;

- controllers' continuing professional development;

- quality assurance of the controllers' work; and

- importance of the aforementioned areas for an effective controlling system in enterprise.

To assure reliable and relevant data, the research team divided the work on the questionnaire into three stages:

- the final aim of the first stage was to verify the completeness and understandability of the questionnaires in individual interviews in the Czech Republic; 21 respondents from the first group and 5 respondents from the second group participated in this stage of the questionnaires' development;

- on the basis of the first phase, keeping in mind future cross-country comparisons, both versions of the general, universal questionnaire were developed into the form which was appropriate for their electronic distribution; and

- finally, questionnaires were translated to national languages (incl. Polish).

\section{Empirical research results}

As the study progresses, the number of completed questionnaires increases. Current status of the empirical part of the research is as follows:

- 25 participants responded to the questions of "A controller should be ..." questionnaire; and

- 24 participants responded to the questions of "A controller is ..." questionnaire.

The empirical research is still being conducted, but the results so far are interesting enough to publish them. The analysis of the responses brought the results discussed further in the paper. 
Král, B. - Mikołajewicz, G. - Nowicki, J. - Šoljaková, L.: Professional Competences of

Controllers: The Case of Poland.

\subsection{Controllers' position in the companies' organizational charts}

The research at the current stage has not given an unequivocal response regarding:

- the controllers' position in the organizational chart;

- the desired structure of the departments which should assure controllers' functions;

- relations of controlling departments to the other departments engaged in various aspects of financial management.

These results can be caused not only by the difficult generalization of progressive tendencies, but also by the different Anglophone and Germanic approaches to these issues which are applied in the companies operating in Poland.

However, most respondents supported (described) a solution in which controllers:

- Are members of the department supervised by the company CFO or direct by CEO;

- Should be situated in the organizational structure on the same level as accounting department or on the higher level; and

- Should provide advisory information to senior managers.

Thus it can be stated, that empirical findings are consistent with the Horváth's understanding of controllers as "the economic conscience of a company" (Horváth, 2006).

\subsection{General content of the controllers' activities}

As far as the general content of the controllers' activities is concerned, the research showed very similar results for both groups of respondents regarding their listing and their evaluation of the importance of individual activities. According to the results, controllers are exclusively responsible for the quality, availability and transparency of the information rendered to managers.

The correctness of input data processed subsequently into the output information used in managerial control is slightly less important, with the result in this area higher for the second group of experts than for the first one. What is important, the difference between both groups is statistically significant at the 5 percent $(\mathrm{p}=$ 0,0398).

In compliance with the above-stated role of a controller as the economic conscience, both groups of experts also confirmed that a controller shouldn't be responsible for the company's financial results. The results for the second group of experts show slightly higher average and mode; however, the difference is not statistically significant. These results can possibly mean that as far as the tested samples are concerned with the first group of experts, they generally reject the responsibility for financial results, but in practice, controllers gain a certain part of their compensation based on financial results. 
In our view, this difference can be explained by the fact that many companies link bonuses of their employees to financial results with the aim to communicate interest in their fulfilment across all company levels, regardless of whether their employees directly influence them or not. This also regards controllers.

The numerical outcomes of the investigation are stated in Table 1.

\section{Tab. 1 General content of controllers' activities}

\begin{tabular}{|c|c|c|c|c|}
\hline \multirow{2}{*}{ Description } & \multicolumn{2}{|c|}{ "Should be" } & \multicolumn{2}{|c|}{ "Is" } \\
\hline & Average & Mode & Average & Mode \\
\hline $\begin{array}{l}\text { Correctness of data processed subsequently into the } \\
\text { output information used in managerial control }\end{array}$ & 3,36 & 4 & 4,04 & 5 \\
\hline $\begin{array}{l}\text { Quality of information rendered to company } \\
\text { management }\end{array}$ & 4,36 & 5 & 4,58 & 5 \\
\hline $\begin{array}{l}\text { Availability of information for company } \\
\text { management }\end{array}$ & 4,20 & 5 & 4,42 & 5 \\
\hline $\begin{array}{l}\text { Transparency of information rendered to company } \\
\text { management }\end{array}$ & 4,44 & 5 & 4,71 & 5 \\
\hline Financial results & 2,52 & 1 & 2,79 & 3 \\
\hline
\end{tabular}

Source: Authors' calculations.

\subsection{Controllers' authority and responsibility}

The next area investigated in the research was controllers' authority and responsibility.

The comparison of both versions of the questionnaire shows the experts' general agreement with the opinion that a controller is (should be) equipped with a sufficient authority and responsibility in the areas in which he/she serves as:

- A communicator who transfers reached results to the relevant management levels and who comments, explains and interprets these results to managers;

- An expert facilitating and supporting communication and coordination between all company management levels;

- A developer who is responsible for the pricing, costing, budgeting and management accounting development (including the terminology used) and who should also devote attention to their adherence;

- An expert preparing scenarios of future solutions for managers;

- A developer of information system or its parts; and finally;

- An expert who participates in the regulation and support of the company financial management development including the system of remuneration and motivation.

In some areas it is apparent that the opinions of both groups differ, However, these differences are not statistically significant. The first difference is the area of coordination of activities connected with formulation of the company objectives and means of their fulfilment. According to the first group of respondents, the role 
of controllers is important in this area, however, according to the second group, controllers do not play such an important role in practice.

The second area with a little lower agreement between both groups of experts is preparation of scenarios for future solutions, where the result for first group of experts ("should be") is on average higher than the result for the second group ("is").

Both groups did not give unambiguous answer to question whether a controller should or should not have authority to influence resource allocation (this refers e.g. to decisions concerning volume and structure of sold products, make-or-buy decisions or decisions about the extension or reduction of customer or distribution channels).

The numerical outcomes of the investigation are stated in Table 2.

\section{Tab. 2 Areas of authority and responsibility}

\begin{tabular}{|c|c|c|c|c|}
\hline \multirow{2}{*}{ Description } & \multicolumn{2}{|c|}{ "Should be" } & \multicolumn{2}{|c|}{ "Is" } \\
\hline & Average & Mode & Average & Mode \\
\hline $\begin{array}{l}\text { Coordination of activities connected with } \\
\text { formulation of the company objectives and means } \\
\text { of their fulfilment }\end{array}$ & 3,80 & 5 & 3,25 & 3 \\
\hline Preparation of scenarios of future solutions & 4,24 & 5 & 3,79 & 5 \\
\hline Development of an information system or its parts & 3,60 & 4 & 3,50 & 3 \\
\hline $\begin{array}{l}\text { Development of directives on pricing, costing, } \\
\text { budgeting and management accounting } \\
\text { development and examination of adherence to } \\
\text { them }\end{array}$ & 3,84 & 3 & 3,83 & 5 \\
\hline $\begin{array}{l}\text { Communication of results reached to relevant } \\
\text { management levels }\end{array}$ & 4,12 & 4 & 4,33 & 5 \\
\hline $\begin{array}{l}\text { Explanation and interpretation of information } \\
\text { rendered to managers }\end{array}$ & 4,28 & 5 & 4,63 & 5 \\
\hline $\begin{array}{l}\text { Facilitation and support of communication } \\
\text { between departments }\end{array}$ & 3,72 & 4 & 3,54 & 3 \\
\hline Decision on resource allocation & 3,20 & 2 & 3,00 & 3 \\
\hline $\begin{array}{l}\text { Participation in the regulations of a company's } \\
\text { financial management development including the } \\
\text { system of remuneration and motivation }\end{array}$ & 3,56 & 3 & 3,42 & 4 \\
\hline
\end{tabular}

Source: Authors' calculations.

\subsection{Specific content of the controllers' activities}

In the specific content of the controllers' activities investigation, the research has recognized the crucial role of controllers in ensuring the companies' target information, i.e. in planning on the strategic, tactical and operational levels, including processing, presentation and explanation of forecasts, estimates and expectations, as well as in participation in the development of management accounting and internal reporting systems. 
The respondents have also highlighted the crucial role of "traditional controllers' task" - adequate information support for acquisition of business resources (fixed assets, inventories, human resources etc.) and management of business processes (research and development, purchasing, production, logistics, production, sale etc.). Both groups of experts acknowledged also the importance of controllers' participation in the development of the organization structures, project management system and risk identification and management system - the significance of these activities was however lower than the previous ones.

It is worth noting that the results of both groups of respondents were very similar in almost all areas. Slight difference between both groups of experts concerns such areas as strategic and tactical planning and budgeting, expectations and forecasts development and enhancement of organization structures, however the differences between both groups are not statistically significant.

The results of this part of the investigation are stated in Table 3.

\section{Tab. 3 Specific content of the controllers' activities}

\begin{tabular}{|c|c|c|c|c|}
\hline \multirow{2}{*}{ Description } & \multicolumn{2}{|c|}{ "Should be" } & \multicolumn{2}{|c|}{ "Is" } \\
\hline & Average & Mode & Average & Mode \\
\hline Strategic planning and budgeting & 4,44 & 5 & 4,21 & 5 \\
\hline Tactical planning and budgeting & 4,48 & 5 & 4,25 & 5 \\
\hline Operational planning and budgeting & 4,44 & 5 & 4,50 & 5 \\
\hline Expectations and forecasts development & 4,00 & 4 & 4,38 & 5 \\
\hline $\begin{array}{l}\text { Participation in the development of management } \\
\text { accounting and internal reporting systems }\end{array}$ & 4,44 & 5 & 4,54 & 5 \\
\hline $\begin{array}{l}\text { Participation in the development of the project } \\
\text { management system }\end{array}$ & 3,56 & 3 & 3,63 & 3 \\
\hline $\begin{array}{l}\text { Participation in the development of the risk } \\
\text { identification and management system }\end{array}$ & 3,64 & 4 & 3,67 & 3 \\
\hline $\begin{array}{l}\text { Information support for acquisition of business } \\
\text { resources and management of processes (research } \\
\text { and development, purchasing, production, logistics, } \\
\text { sale etc.) }\end{array}$ & 3,96 & 4 & 4,04 & 4 \\
\hline $\begin{array}{l}\text { The development and enhancement of organization } \\
\text { structures including follow-up activities }\end{array}$ & 3,56 & 3 & 3,83 & 4 \\
\hline
\end{tabular}

Source: Authors' calculations.

\subsection{Requirements for education}

Substantial part of both questionnaires was devoted to the requirements on the controllers' education. This section of the questionnaires was based on the structure of requirements defined by IFAC (2003) International Education Standards and UNCTAD (2011) Revised Model Accounting Curriculum.

The aims, content and structure of the pre-qualification programmes of the Chamber of Auditors in Czech Republic and Poland, the Union of Accountants and the ACCA, and syllabuses of the master-degree specializations of Accounting 
and Company Financial Management and Controllership taught at the Faculty of Finance and Accounting of the University of Economics, Prague as well as corresponding syllabuses from Poznań University of Economics and Business were also taken into the consideration.

As it can be seen from Table 4, both groups of respondents have emphasized the importance of knowledge of financial accounting and reporting, management accounting and corporate finance. According to both groups of experts, knowledge of auditing, internal control systems, management, business administration and quantitative methods are other areas of controllers' knowledge relevant to their work.

Conversely, knowledge of labour law, social and health insurance law and especially marketing is not so important for controllers' activities according to both groups of experts.

The largest discrepancies in opinions of both groups of experts concern business law, labour law, social and health insurance law and taxation (where the results for the first group is higher than for the second group) as well as economics (where the results are higher for the second group), however differences concerning taxation, labour law and social and health insurance law are statistically significant at the 10 percent (accordingly: $\mathrm{p}=0,0727, \mathrm{p}=0,0928, \mathrm{p}=0,0590$ ) and the difference between opinions of both groups of experts concerning economics is statistically significant at the 5 percent $(\mathrm{p}=0,0392)$.

\section{Tab. 4 Requirements for education}

\begin{tabular}{lllll}
\hline \multirow{2}{*}{$\begin{array}{l}\text { Controller should be able to use knowledge from } \\
\text { the following areas: }\end{array}$} & \multicolumn{2}{c}{ "Should be" } & \multicolumn{3}{c}{ "Is" } \\
\cline { 2 - 5 } & Average & Mode & Average & Mode \\
\hline Financial accounting and reporting & 4,64 & 5 & 4,67 & 5 \\
Management accounting & 4,80 & 5 & 4,79 & 5 \\
Corporate finance & 4,48 & 5 & 4,42 & 5 \\
Taxation & 3,96 & 5 & 3,46 & 4 \\
Business law & 3,72 & 4 & 3,29 & 4 \\
Labour law & 3,32 & 3 & 2,75 & 3 \\
Social and health insurance law & 3,20 & 3 & 2,54 & 3 \\
Auditing & 4,04 & 5 & 3,83 & 4 \\
Internal control systems & 4,20 & 5 & 4,21 & 5 \\
Economics & 3,68 & 5 & 4,29 & 5 \\
Management & 3,92 & 5 & 4,04 & 5 \\
Business administration & 4,00 & 5 & 4,13 & 5 \\
Marketing & 2,88 & 3 & 2,96 & 3 \\
Quantitative methods (Mathematics, Statistics) & 4,16 & 5 & 4,25 & 4 \\
\hline
\end{tabular}




\begin{tabular}{lllll}
\hline \multirow{2}{*}{$\begin{array}{l}\text { Controller should be able to use knowledge from } \\
\text { the following areas: }\end{array}$} & \multicolumn{2}{c}{ "Should be" } & \multicolumn{2}{c}{ "Is" } \\
\cline { 2 - 5 } & Average & Mode & Average & Mode \\
\hline International aspects of business & 3,52 & 4 & 3,50 & 3 \\
Information and communication technology (ICT) & 3,68 & 4 & 3,63 & 4 \\
\hline
\end{tabular}

Source: Authors' calculations.

\subsection{Requirements for ICT competencies}

Although ICT knowledge formed one of the sections of the requirements for education, special part of the questionnaire was also devoted to ICT competencies. The reason is obvious: all companies' as well as controllers' activities take place in ICT environment. Therefore it is not possible to realise all the above-mentioned tasks and responsibilities without ICT knowledge. Besides that, the crucial impact of ICT on controllers' work was emphasized in many of the aforementioned literature sources.

Generally, both groups of respondents agreed that fast development of ICT has changed the substance of controllers' work. On the other hand, controllers are increasingly required to participate actively in the development of the companies' ICT systems.

Concerning more specific areas of research, the purpose of both versions of the questionnaire was to define the controllers' role(s) in the area of ICT: the respondents have been asked whether controllers (should) act as users of ICT only or whether they (should) also participate actively in ICT development. According to both groups' responses, controllers are considered to be ICT users rather than creators. They are also considered to originate and verify processing quality rather than user quality. Both groups also agreed with the statement that controllers should not serve (do not serve) as managers of ICT projects.

The results of this part of investigation are stated in Table 5.

\section{Tab. 5 ICT competencies}

\begin{tabular}{lllll}
\hline \multirow{2}{*}{ In the area of ICT a controller acts especially as: } & \multicolumn{2}{c}{ "Should be" } & \multicolumn{2}{c}{ "Is" } \\
\cline { 2 - 5 } & Average & Mode & Average & Mode \\
\hline User (with stress on areas he/she uses) & 4,16 & 5 & 3,96 & 5 \\
Creator (with stress on areas he/she uses) & 3,28 & 3 & 3,67 & 4 \\
Originator or verifier of processing quality & 3,76 & 4 & 3,92 & 5 \\
Originator or verifier of user quality & 3,52 & 4 & 3,54 & 4 \\
Manager of ICT projects or their parts & 2,64 & 2 & 3,04 & 3 \\
\hline
\end{tabular}

Source: Authors' calculations. 


\subsection{Requirements for professional skills and practical experience}

The following area investigated during the study refers to professional skills and practical experience which controllers (should) obtain to be able to act competently. The exact structure of this area was derived from overview of abovementioned skills stated especially in IFAC (2003) International Education Standard 3 - Professional skills.

As it is apparent from the Table 6, both groups of experts consider all the stated soft skills as relatively very important for controllers' work - although they evaluate the first four ones as being even more important than the fifth. Presentation skills are the most obvious requirement for professional controller in the opinion of both groups of respondents.

\section{Tab. 6 Requirements for professional skills and practical experience}

\begin{tabular}{|c|c|c|c|c|}
\hline \multirow{2}{*}{$\begin{array}{l}\text { It is important for a controller to develop } \\
\text { especially: }\end{array}$} & \multicolumn{2}{|c|}{ "Should be" } & \multicolumn{2}{|c|}{ "Is" } \\
\hline & Average & Mode & Average & Mode \\
\hline Communication skills & 4,28 & 5 & 4,46 & 5 \\
\hline $\begin{array}{l}\text { Ability to deal with people and assert his/her } \\
\text { opinions }\end{array}$ & 4,20 & 5 & 4,08 & 5 \\
\hline Presentation skills & 4,52 & 5 & 4,75 & 5 \\
\hline Managerial and organizational skills & 4,16 & 4 & 4,04 & 5 \\
\hline Language knowledge including ability to use it & 3,88 & 4 & 3,71 & 4 \\
\hline
\end{tabular}

Source: Authors' calculations.

\subsection{Controllers' role in ethical aspects of business}

Regarding ethical aspects of business, both groups of respondents generally agree with the statement that - despite the fact that this area was undervalued for a long time - recently it has been very important for a company to define, enhance, support and communicate effectively ethical principles and rules of business as well as to incorporate them into company standards, codes and guidelines.

In contrast to this general belief, our investigation found (according to both groups of respondents) that there is a relatively low level of controllers' participation in development, inspection and fulfilment of ethical standards, codes and guidelines in a company.

As it is apparent from the following table, the role of controllers in the process of ethical principles enforcement is unsatisfactory. While the standards and guidelines devoted to ethical aspects of professional accountants' activities evaluate this section of controllers' work as quite important, controllers seem to engage those activities not so often.

The results of this part of investigation are stated in Table 7. 


\section{Tab. 7 Controllers' role in ethical aspects of business}

\begin{tabular}{|c|c|c|c|c|}
\hline \multirow{2}{*}{ Description } & \multicolumn{2}{|c|}{ "Should be" } & \multicolumn{2}{|c|}{ "Is" } \\
\hline & Average & Mode & Average & Mode \\
\hline $\begin{array}{l}\text { It is important for a company to define, enhance, } \\
\text { support and communicate effectively the ethical } \\
\text { principles and rules of business }\end{array}$ & 4,20 & 5 & 4,29 & 5 \\
\hline $\begin{array}{l}\text { These principles and rules are explicitly incorporated } \\
\text { into company standards, codes and guidelines }\end{array}$ & 4,12 & 5 & 4,21 & 5 \\
\hline $\begin{array}{l}\text { Controller participates in the development of ethical } \\
\text { company standards, codes and guidelines }\end{array}$ & 3,48 & 3 & 3,42 & 3 \\
\hline $\begin{array}{l}\text { In the scope of his/her authorities and responsibilities, } \\
\text { the controller participates in the inspection of how } \\
\text { these standards, codes and guidelines are fulfilled }\end{array}$ & 3,72 & 4 & 3,67 & 4 \\
\hline $\begin{array}{l}\text { Controller serves as an informal authority in the } \\
\text { fulfilment of these standards, codes and guidelines - } \\
\text { in the internal company environment as well as } \\
\text { externally }\end{array}$ & 3,28 & 4 & 3,08 & 3 \\
\hline
\end{tabular}

Source: Authors' calculations.

\subsection{Human resources management}

The section "human resources management" focused on two problem areas:

- The selection of potential candidates for a controller position; and

- The importance of their continuing professional development.

Especially in the first section, there is a great level of agreement between both groups of respondents in reaction to all statements.

Both groups believe that the education, practical experience, ability to deal with people and personality profile as well as communication skills are the most important characteristics of candidates for a controllers position (the responses in "Is" group are slightly higher for all of the statements; however, the difference is not statistically significant). Also the ICT competencies play an important role.

Both groups of respondents have paid less attention to language knowledge. It is worth noting that language skills are more appreciated by practice.

The concrete results of the investigation are shown in Table 8 .

\section{Tab. 8 Selection of potential candidates for a controller position}

\begin{tabular}{lllll}
\hline \multirow{2}{*}{$\begin{array}{l}\text { In the process of a potential controller selection it } \\
\text { is important to take into consideration: }\end{array}$} & \multicolumn{2}{c}{ "Should be" } & \multicolumn{2}{c}{ "Is" } \\
\cline { 2 - 5 } & Average & Mode & Average & Mode \\
\hline Previous education & 4,08 & 4 & 4,25 & 4 \\
Present practical experience & 4,56 & 5 & 4,71 & 5 \\
Ability to deal with people and personality profile & 4,32 & 5 & 4,63 & 5 \\
Communication abilities and skills & 4,32 & 5 & 4,67 & 5 \\
ICT competencies & 3,96 & 4 & 3,92 & 4 \\
Language knowledge & 3,52 & 4 & 3,83 & 4 \\
\hline
\end{tabular}

Source: Authors' calculations. 
Concerning controllers' professional development, both groups of experts confirmed that very important factor for the quality of controllers' work is to continue professional development.

The research also found that management should and generally enables the companies' controllers to take part in professional development and verifies whether controllers enhance their professional competencies (the responses to the second matter are slightly lower than for the first one).

Both groups are also more or less unanimous in their opinion that the remuneration of controllers should be (is) slightly higher in comparison with employees operating at the same organizational level.

Surprisingly, according to the first group of experts, it is not so important that controlling departments consist of a stable team of experts who do not change very often and the difference between opinions of both groups is statistically significant at the 1 percent $(p=0,0053)$. On the other hand, practice shows that there's not much rotation in the controllers team in companies.

The concrete results of this part of investigation are shown in Table 9.

Tab. 9 Controllers' professional development

\begin{tabular}{|c|c|c|c|c|}
\hline \multirow{2}{*}{ Description } & \multicolumn{2}{|c|}{ "Should be" } & \multicolumn{2}{|c|}{ "Is" } \\
\hline & Average & Mode & Average & Mode \\
\hline $\begin{array}{l}\text { Controlling department consists of a stable } \\
\text { team of experts who do not change very often }\end{array}$ & 3,32 & 4 & 4,13 & 5 \\
\hline $\begin{array}{l}\text { In comparison with employees operating at the } \\
\text { same organizational level, controllers are paid } \\
\text { above average }\end{array}$ & 4,08 & 4 & 3,71 & 5 \\
\hline $\begin{array}{l}\text { Continuing professional development is quite } \\
\text { important for the quality of the controllers' } \\
\text { work }\end{array}$ & 4,40 & 5 & 4,42 & 5 \\
\hline $\begin{array}{l}\text { Company management enables its controllers } \\
\text { to continue their professional development }\end{array}$ & 3,92 & 5 & 4,13 & 4 \\
\hline $\begin{array}{l}\text { Company management verifies whether } \\
\text { controllers enhance their professional } \\
\text { competence }\end{array}$ & 3,64 & 4 & 3,54 & 4 \\
\hline
\end{tabular}

Source: Authors' calculations.

\subsection{Quality assurance of the controllers' activities}

The content and structure of those parts of the questionnaire which was devoted to quality assurance was derived from the preceding parts devoted to general and specific contents of controllers' activities and to their authority and responsibility.

Responses gained from this part generally confirm the necessity of evaluation of controllers' activities (in all aspects of their work). What is interesting is nearly half of the respondents (in both groups of experts) agreed that instead of a regular 
basis, the evaluation can be done ad hoc based on dissatisfaction with the submitted information. Quality assurance should be (is) provided mainly by CFO, then directly by top management or superior holding department (internal audit department was indicated only by the first group of experts).

In this regard, it is quite apparent that development of quality standards for controllers could enhance the general awareness of how to assure higher quality of the profession for a future; the results of this research could be used as one of the sources for their development.

The results of this part of investigation are stated in Table 10.

\section{Tab.10 Quality assurance of controllers' work}

\begin{tabular}{lllll}
\hline \multirow{2}{*}{ Description } & \multicolumn{2}{c}{ "Should be" } & \multicolumn{2}{c}{ "Is" } \\
\cline { 2 - 5 } & Average & Mode & Average & Mode \\
\hline $\begin{array}{l}\text { Controllers' work quality is regularly checked } \\
\text { and evaluated }\end{array}$ & 3,72 & 3 & 3,67 & 5 \\
Controllers' work quality assurance includes: & & & & \\
$\quad$ - Correctness of input data & 3,96 & 5 & 4,38 & 5 \\
- Information relevance & 4,28 & 5 & 4,67 & 5 \\
- Timeliness of rendered information & 4,48 & 5 & 4,54 & 5 \\
- Formal level of rendered information & 4,36 & 5 & 4,75 & 5 \\
- Neutrality and objectivity of information & 4,44 & 5 & 4,46 & 5 \\
- Information flexibility & 3,92 & 5 & 3,88 & 4 \\
- Information comparability and consistency & 4,40 & 5 & 4,79 & 5 \\
\hline
\end{tabular}

Source: Authors' calculations.

\subsection{Importance of analysed areas for an effective controlling system in enterprise}

As it is apparent from the Table 11, both groups of experts stated that the most important area for an effective controlling system in enterprise is area "requirements for professional skills and practical experience". Almost equally important is controller position in company, general and specific activities as well as requirements for education and ICT competencies. Slightly less essential is subject of assurance of quality of controllers' work.

Although the topic of ethical aspects of business gained much interest in recent years, companies and also academic experts rated this matter as not so important for the effectiveness of controlling system. Neither is the process of selecting candidates and controller's professional development. It seems that effectiveness is still being perceived in the sense of achieving specific goals and financial outcomes rather than sustainable development. 
Král, B. - Mikołajewicz, G. - Nowicki, J. - Šoljaková, L.: Professional Competences of

Controllers: The Case of Poland.

\section{Tab. 11 Importance of an analysed areas for an effective controlling system} in enterprise

\begin{tabular}{|c|c|c|c|c|}
\hline \multirow{2}{*}{ Description } & \multicolumn{2}{|c|}{ "Should be" } & \multicolumn{2}{|c|}{ “Is" } \\
\hline & Average & Mode & Average & Mode \\
\hline $\begin{array}{l}\text { Position of the controller in a corporate } \\
\text { organizational structure }\end{array}$ & 4,12 & 4 & 4,33 & 5 \\
\hline $\begin{array}{l}\text { General content of the controllers' activities and } \\
\text { areas of authority and responsibility }\end{array}$ & 4,24 & 4 & 4,04 & 4 \\
\hline Specific content of the controllers' activities & 4,24 & 4 & 4,08 & 4 \\
\hline Requirements for education and ICT competencies & 4,28 & 5 & 4,42 & 5 \\
\hline $\begin{array}{l}\text { Requirements for professional skills and practical } \\
\text { experience }\end{array}$ & 4,44 & 5 & 4,54 & 5 \\
\hline Controllers' role in ethical aspects of business & 3,40 & 4 & 3,38 & 4 \\
\hline $\begin{array}{l}\text { Selection of potential candidates for a controller } \\
\text { position and controllers' professional development }\end{array}$ & 3,36 & 4 & 3,25 & 3 \\
\hline Quality assurance of controllers' work & 3,88 & 4 & 4,08 & 4 \\
\hline
\end{tabular}

Source: Authors' calculations.

\section{Conclusions}

Although the results of the project were based on a limited number of responses and examined the situation in Poland only, they are very interesting and have already brought inspirations both in the area of conceptual ideas as well as the empirical research outcomes.

The results of empirical research have already contributed to a better understanding of:

- The development of the controllers' work in a different part of the globe; and

- The profiles and professional orientations of controllers (management accountants) in business.

The outcomes of the empirical research can also contribute to the development of "Standards of good practice". The standards of good practice which should include:

- The aims, content and structure of pre-qualification education as well as requirements for the assessment of the required level of knowledge;

- The requirements for controllers' professional skills and how they can be acquired;

- The methods that allow to gain practical experience as well as the instruments, manners and ways of its verification;

- The aims, content, structure of realization and methods of efficient verification of controllers' continuing professional development; and

- A code of ethics as a principal document that enforces professional approaches, values and attitudes in the work of these experts. 
Some specific suggestions which should be incorporated into the abovementioned "Standards of good practice" can also be derived from the research investigations:

- Controllers should be members of the department supervised by CFO or direct by CEO as well as be situated in the organizational structure on the same or higher level as accounting department;

- Controllers should act as the economic conscience of a company. They should be responsible primarily for the quality, availability and transparency of the information rendered to managers; conversely, they should not be responsible primarily for the financial results of a company;

- Main areas of controller's authority and responsibility include communication, explanation, interpretation of the results and coordination between all company levels, development of directives on pricing, costing, budgeting and management accounting as well as preparation of scenarios;

- Current research acknowledged the crucial role of controllers in planning and budgeting on the strategic, tactical and operational levels, including processing, presentation and explanation of forecasts, estimates and expectations, as well as in participation in the development of management accounting and internal reporting systems;

- Regarding education, financial accounting and reporting, management accounting and corporate finance knowledge are especially important for controllers' work; other relevant areas of controllers' knowledge include auditing, internal control systems, management, business administration and quantitative methods;

- Concerning the ICT area, controllers should be perceived mainly as users rather than creators. They are also considered to originate and verify processing quality rather than user quality;

- Regarding the area of professional skills and practical experience, it is necessary to develop pre-conditions for the development of communication skills, ability to deal with people and assert his/her opinions and presentation skills which seem to be the most important for controllers' work;

- The research has confirmed that it is very important for a company to define, enhance, support and communicate effectively ethical principles and rules as well as to incorporate them into company standards, codes and guidelines; unfortunately, the investigation has also shown relatively low level of controllers participation in development, inspection and fulfilment of ethical standards, codes and guidelines in company; this aspect should be incorporated into the quality standards of the controllers' work since it is very important;

- The research has also confirmed that the education, practical experience, ability to deal with people and personality profile as well as communication skills are the most important characteristics of candidates for a controllers position; also 
the ICT competencies play an important role;

- The project results show, that continuing professional development is very important for the quality of all controllers' activities; in this regard, it is necessary to find ways so that managers not only enable controllers to deepen their competence in professional development, but also verify whether controllers enhance their competences continuously;

- Regarding quality assurance of controllers' work, it can be stated that both groups of experts generally confirm the necessity of evaluation of controllers' activities (in all aspects of their work); Quality assurance should (is) be provided mainly by CFO, then directly by top management or superior holding department (internal audit department was indicated only by the first group of experts);

- Concerning the importance of analysed areas for an effective controlling system in enterprise, project results confirm that the most important are requirements for professional skills and practical experience. Almost equally important are controller position in company, general and specific activities as well as requirements for education and ICT competencies. Slightly less essential is subject of assurance of quality of controllers' work. Both ethical aspects of business and process of selecting candidates and controller's professional development were rated relatively lower, what shows that effectiveness is still being perceived in the sense of achieving specific goals and financial outcomes rather than sustainable development.

\section{References}

Bieńkowska, A., Kral, Z., Zabłocka-Kluczka, A., 2014. Rozwiązania organizacyjne controllingu w organizacjach sieciowych, in: Nowak, E., Nieplowicz, M. (ed.), Rachunkowość a controlling. Prace Naukowe Uniwersytetu Ekonomicznego we Wrocławiu nr 344, Wrocław, 53-69. DOI: 10.15611/pn.2014.344.05.

Burns, J., Yazdifar, H., 2001., Trick or treats? Financial Management 3, 33-35.

Carruth, B., 2004. Management Accounting - what's new? Chartered Accountants Journal 9, 29-30.

CIMA, 2000. Management Accounting. Official Terminology, London, Chartered Institute of Management Accountants.

CIMA, 2008. Improving Decision Making in Organizations. The Opportunity to Reinvent Finance Business Partners, London, Chartered Institute of Management Accountants.

CIMA, 2009. Management Accounting Tools for Today and Tomorrow, London, Chartered Institute of Management Accountants.

Foremna-Pilarska, M., 2015. Controlling. Narzędzia i struktury, PWE, Warszawa 
Gmińska, R., 2014. Aspekty behawioralne w rachunkowości zarządczej, in: Nowak, E., Nieplowicz, M. (ed.), Rachunkowość a controlling. Prace Naukowe Uniwersytetu Ekonomicznego we Wrocławiu nr 344, Wrocław, 185-193. DOI: 10.15611/pn.2014.344.15.

Grandlund, M., Lukka, K., 1998. Towards increasing business orientation: Finish management accountants in a changing cultural context. Management Accounting Research 2, 185-211. DOI: 10.1006/mare.1998.0076.

Hoper, T., 1980. Role conflicts of management accountants and their position within organization structures. Accounting organization and Society 4, 129-55. DOI: 10.1016/0361-3682(80)90039-2.

Horváth, P., 2006. Das Controllingkonzept. Der Weg zu einem wirkungsvollen Controllingsystem. München: DTV Verlag Valen Beck.

IFAC, 2003. International Education Standards for Professional Accountants. International Federation of Accountants, New York.

International Group of Controlling, 2010. Controller-Wörterbuch. SchäfferPoeschle Verlag fur Wirtschaft Steuern Recht, Stuttgart.

International Group of Controlling, 2011. Controller Process Model. Haufe Verlag, Freiburg.

Jablonsky, F. S., Keating, P. J., Heian, J. B., 2004. Business Advocate or Corporate Policeman. Financial Research Foundation, New York.

Janczyk-Strzała, E., 2008. Controlling w przedsiębiorstwach produkcyjnych. $\mathrm{CeDeWu}$, Warszawa.

Janik, W., Paździor, M., 2012. Rachunkowość zarządcza i controlling. Politechnika Lubelska, Lublin.

Jaruga, A., Nowak, W., Szychta, A., 1999. Rachunkowość zarządcza. Koncepcje i zastosowania, Absolwent, Łódź.

Kaplan, R., Anderson, S., 2007. Time-Driven Activity-Based Costing. A Simpler and More Powerful Path to Higher Profits. Harvard Business School Press (Polish edition 2008 by Wydawnictwo Naukowe PWN, Warszawa).

Kaplan, R., Cooper, R., 1998. Cost and Effect: Using Integrated Systems to Drive Profitability and Performance. Harvard Business School Press, Boston.

Kes, Z., 2013. Organizacyjne aspekty controllingu, in: Nowak E. (ed.). Controlling dla menedżerów, CeDeWu, Warszawa.

Král, B., Šoljaková, L., 2014. Requirements on controllers in the Czech Republic. An empirical study, Zeszyty Teoretyczne Rachunkowości 78, 151-175. DOI: 10.5604/16414381.1122878.

Král, B., Šoljaková, L., 2015. Professional competence requirements on controllers in the Czech Republic: An empirical study. International conference 
„Finance and performance of firms in science, education and practice“, Tomas Bata University in Zlín, April 23-24, 2015.

Král, B., Šoljaková, L. (2016), Development of Controllers' Professional Competence: the case of Czech Republic. Economics and Sociology 1, 11-31. DOI: 10.14254/2071-789X.2016/9-1/6.

Marciniak, S., 2008. Controlling. Teoria, zastosowania. Difin, Warszawa, 23-31.

Merchant, K., 2003. Management control systems: performance measurement, evaluation and incentives. Prentice Hall / Pearson Education, Harlow.

Nowak, M., 2013. Praca w controllingu a przybierane role grupowe. Analiza wyników badań empirycznych, in: Nowak, E., Nieplowicz, M. (ed.), Systemy rachunku kosztów i kontroli zarządczej. Prace Naukowe Uniwersytetu Ekonomicznego we Wrocławiu nr 289, Wrocław, 438-448.

Nowak, M., 2014a. Male and Female Controllers. Between Controlling and Gender Studies, in: Nita, B. (ed.), Performance Measurement and Management. Research Paper of Wrocław University of Economics nr 345, Wrocław, 86-93. DOI: $10.15611 / \mathrm{pn} .2014 .345 .08$.

Nowak, M., 2014b. Znaczenie wymiarów czasu w controllingu - definicje teoretyczne a psychologiczna charakterystyka controllerów, w: Nowak, E., Nieplowicz, M. (ed.), Rachunkowość a controlling. Prace Naukowe Uniwersytetu Ekonomicznego we Wrocławiu nr 344, Wrocław, 185-193. DOI: 10.15611/pn.2014.344.37.

Parker, L., 2002. Reinventing the management accountant. Transcript of CIMA address delivered at Glasgow University, 15 March.

Pierce, B., O'Deam, T., 2003. Management accounting information and the needs of managers: perceptions of managers and accountants compared. British Accounting Review 3, 257-290. DOI: 10.1016/s0890-8389(03)00029-5.

Sierpińska, M., Niedbała, B., 2003. Controlling operacyjny w przedsiębiorstwie. Wydawnictwo Naukowe PWN, Warszawa.

Simons, R., 2004. Performance Measurement and Control Systems for Implementing Strategy. Prentice Hall, New Jersey.

Steinke, K-H., Schulze, M., Berlin, S., Stehle, A., Georg, J., 2014. Green Controlling. Internationaler Controller Verein, Haufe, Freiburg.

Szychta, A., 2011. Rachunkowość zarządcza jako działalność zawodowa w kontekście doświadczeń zagranicznych. Zeszyty Teoretyczne Rachunkowości 62, Warszawa.

UNCTAD, 2011. Revised Model Accounting Curriculum. United nations Conference on trade and Development, Geneva. 
Yasin, M. M., Bayes, P. E., Czuchry, A. J., 2005. Changing role of accounting in supporting the quality and customers goals of organizations: an open system perspectives. Journal of Management 3, 322-331.

Zralý, M., 2007. Integration Concept of Management Control and its Contribution to Performance Management; in Proceedings of EIASM 4th Conference on Performance Measurement and Management Control, Nice. 
